\title{
How the Natural Sedatives Hawthorn, Mint and Valerian Affect The Orthostatic Test by Measuring Pulse Rate Variability (PRV) in A 60-Year-Old Man
}

\author{
Ivan Domuschiev* \\ Department of Internal Diseases, Plovdiv City, Bulgaria
}

*Corresponding author: Ivan Domuschiev, Department of Internal Diseases, Multiprofile Transport Hospital, Plovdiv City, Bulgaria

\begin{tabular}{|c|c|}
\hline ARTICLE INFO & ABSTRACT \\
\hline Received: 慧 May 06, 2021 & $\begin{array}{l}\text { Citation: Ivan Domuschiev. How the Natural Sedatives Hawthorn, Mint and Valerian } \\
\text { Affect The Orthostatic Test by Measuring Pulse Rate Variability (PRV) in A 60-Year- }\end{array}$ \\
\hline Published: 曲 May 12, 2021 & Old Man. Biomed J Sci \& Tech Res 35(4)-2021. BJSTR. MS.ID.005748. \\
\hline
\end{tabular}

\section{Case Report}

The measuring of Pulse Rate Variability (PRV) and the performing an orthostatic test is a very important method for the examining of the autonomic nervous system. This study shows the state of the sympathetic-vagal balance and indirectly the hormones that are associated with it. In this regard, this method is very important to study also the stress and the adaptive mechanisms of a person to it. The measurements of PRV and orthostatic test were performed at 8 o'clock in the morning at complete rest (see Figure 1). The subject of the study was a 60 -year-old man with a height of $187 \mathrm{~cm}$, weight $75 \mathrm{~kg}$ and $\mathrm{BMI}=24$. The study was performed with the device "Heart Rhythm Scanner" (Biocom Technologies - USA). The PPG-sensor as clip was placed on the index finger of the subject's left hand. The measurement of the same parameters of the PRV + orthostatic test was performed in the same person after taking 2 standardized tablets with the triple combination of hawthorn, mint and valerian (see Figure 2). You can compare the indicators from these 2 figures with the obtained results. In this case, the effect of the triple combination of hawthorn, mint and valerian on the parameters of PRV and the orthostatic test is presented [1-6].

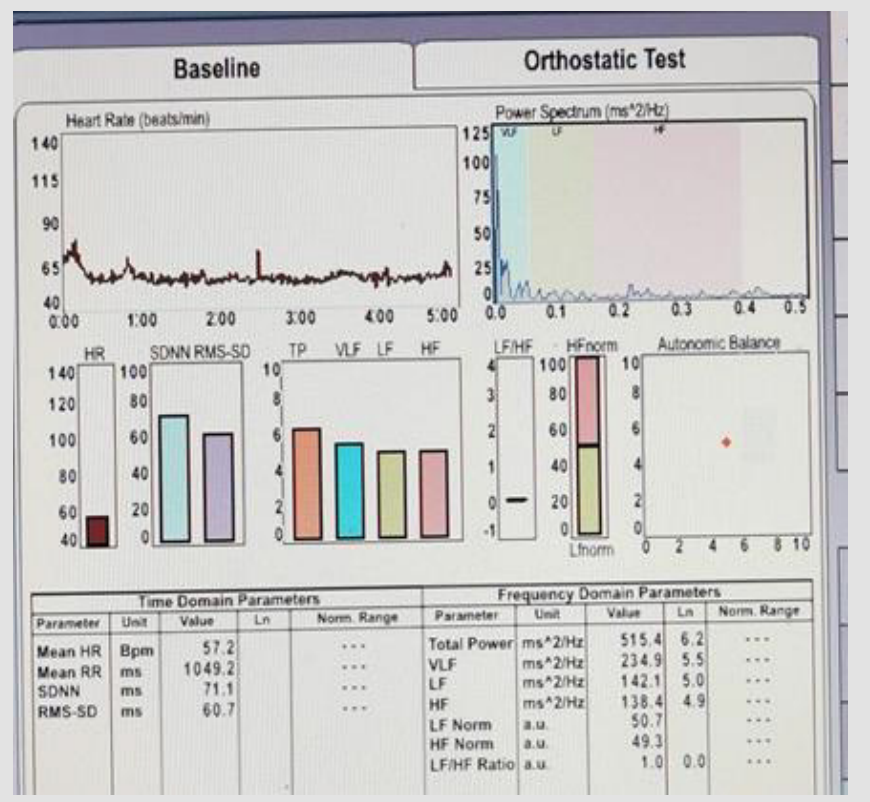

Figure 1: In the morning before the intake of 2 tablets with natural sedatives 


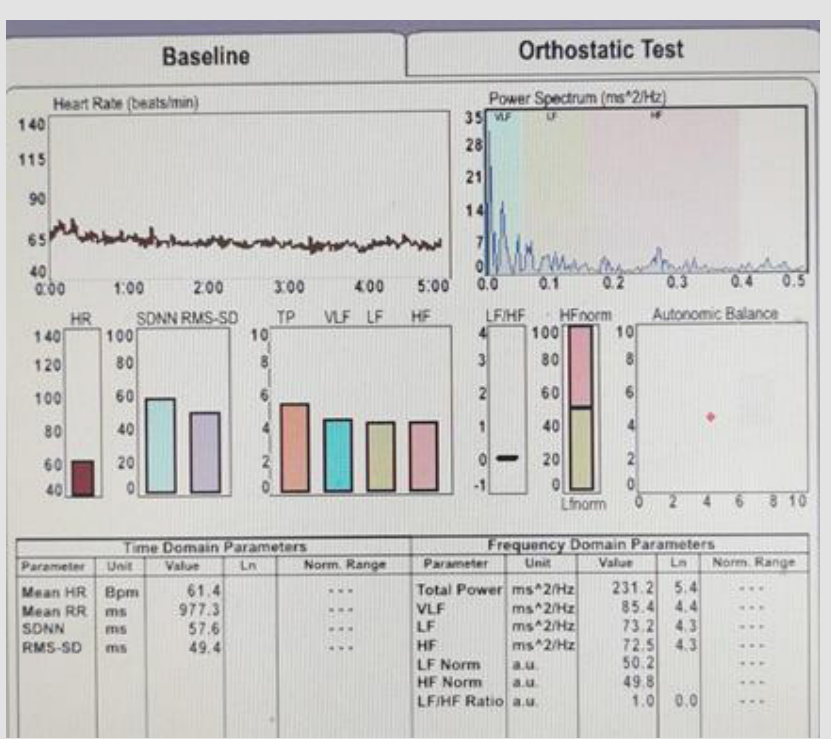

Figure 2: After the intake of 2 tablets with natural sedatives.

\section{ISSN: 2574-1241}

DOI: 10.26717/BJSTR.2021.35.005748

Ivan Domuschiev. Biomed J Sci \& Tech Res

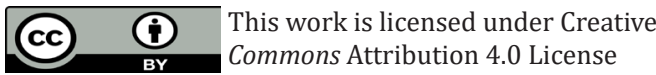

Submission Link: https://biomedres.us/submit-manuscript.php

\section{References}

1. Bulte Carolien SE, Keet Sander WM, Boer Christa, Bouwman R Arthur (2011) Level of agreement between heart rate variability and pulse rate variability in healthy individuals, European Journal of Anaesthesiology 28(1): $34-38$

2. Hoog Antink C, Mai Y, Peltokangas M, Leonhardt S, Oksala N, et al. (2021) Accuracy of heart rate variability estimated with reflective wrist-PPG in elderly vascular patients. Sci Rep 11(1): 8123.

3. Hynynen E, Konttinen N, Kinnunen U, Kyröläinen H, Rusko H (2011) The incidence of stress symptoms and heart rate variability during sleep and orthostatic test. Eur J Appl Physiol 111(5): 733-741.

4. Reland S, Ville NS, Wong S, Guy C, F Carre (2005) Reliability of heart rate variability in healthy older women at rest and during orthostatic testing. Aging Clin Exp Res 17: 316-321.

5. Marcos Antonio Almeida-Santos, Jose Augusto Barreto-Filho, Joselina Luzia Menezes Oliveira, Francisco Prado Reis, Cristiane Costa da Cunha Oliveira, et al. (2016) Aging, heart rate variability and patterns of autonomic regulation of the heart, Archives of Gerontology and Geriatrics 63: 1-8.

6. Plaza-Florido A, Migueles JH, Sacha J, Ortega FB (2019) The role of heart rate in the assessment of cardiac autonomic modulation with heart rate variability. Clin Res Cardiol 108(12): 1408-1409.

$\begin{array}{ll}\text { BIOMEDICAL } & \text { Assets of Publishing with us } \\ \text { RESEARCHES } & \text { - Global archiving of articles } \\ \text { - Immediate, unrestricted online access }\end{array}$

